\title{
Syncritism in Pentecost-Charismatic Movement
}

\author{
Fredy Simanjuntak, ${ }^{* 1}$ Alexander Djuang Papay ${ }^{2}$ \\ Theology Study Program, Real Theological Seminary Batam \\ fredysim@sttrealbatam.ac.id
}

\begin{abstract}
The history of the church notes that to this day the Protestant Church is a family whose history is most often divided. Nevertheless the development is quite significant in the present. The process of developing the church resulted in various streams in the church such as Lutheran, Calvinist, Baptist, Methodist, Pentecostal, Charismatic, Evangelical, Adventist, until Jehovah's Witnesses, in the course of the Pentecostal \& Charismatic flow so fertile in today's growth. The flow of Pentecostalism and Charismaticism, in its origin and method, has a unique and phenomenal history in Indonesia. The uniqueness of Indonesia's spiritual context is illustrated by rapid growth. The Pentecostal and Charismatic movements felt their influence in various churches around us. Phenomena such as the ability to speak in tongues, healing, and prophecy and aspects of emotional experience that are so prominent in this movement make the public wonder, is it true that all of this is the work of the Holy Spirit? The purpose of this paper is to provide an observation of facts, spiritual life background, the meaning of faith, and understanding of the role of the Holy Spirit adopted by followers of the Pentecost-Charismatic Movement in the context of the challenges of contextualization and syncretism in the relationship between Pentecostal-Charismatic and Christian spirituality in Indonesia. In light of the significant regional diversity in Indonesian religious thought and experience, the scope of this research is limited to the idea of contextualization also limited to its use in the missiological context.

Keywords: Syncritism, Pentecost-Charismatic, Movement
\end{abstract}

\section{INTRODUCTION}

The phenomenon of syncretism can be categorized into three main categories, namely religious syncretism and religion, religious syncretism with religious philosophy and syncretism with culture. These three categories of syncretism need to be clearly understood, especially from a Christian perspective so that they can be used in studies of the Pentecostal-Charismatic school. This is important to avoid the wrong understanding of religion and the Christian community itself.

\section{METHOD}

Metode This research is a textual analysis based on a comparison of pentecostal and charismatic theology that aims to evaluate the teachings that develop in the flow of the modern church with the most relevant biblical views so that the church is protected from syncretism. 


\section{RESULTS AND DISCUSSION \\ Definition and Concept of Syncretism}

Syncretism comes from the Greek synretismos, which means union (together, derived from the word sun) cities on the island of Crete (in the Mediterranean). From there, comes the word synkretizein, "united to face the common enemy". There is no similarity or togetherness. However, facing the threat of enemies from outside the island of Crete, they were all in association, although there had been different interests. So syncretism is a non-theological term, instead it tends to be practical. In his book E.G. Singgih cites the term used in the field of religion and theology to show at least four meanings: ${ }^{1}$

1. In an effort to reconcile conflicting opinions or beliefs

2. As an effort to compromise carelessly, an ecletism, namely the attitude of picking a few points from here and rejecting some points from there; reject some from here and instead receive some points from there. The process of eclectic selection often produces something that is illogical or inconsistent.

3. The process of development or a history of growth that has to do with beliefs and practices through association with others.

4. Unity or mixing of previously different forms.

The first, third and fourth meanings have a rather positive connotation. It is natural for people to try to reconcile two opinions that were contradictory. The attempt to reconcile is not necessary to compromise the truth, but to try to reconcile the two aspects of truth under the light of truth itself. While this term in terms of religion by Berkhof and Enklaar is called "Mixing these religions is called syncretism. 2" While Josh McDowell in his book mentions that "Syncretistic" means "tending to reconcile different beliefs, as philosophy and religion". Syncretistic "means" tends to reconcile different beliefs, as philosophy and religion. $^{3}$

Rooted in certain situations and conditions means rooted in certain cultures. This culture can contain religious aspects. Usually in Indonesia these religious aspects we call "spiritual culture". That is to say: Indonesians who embrace Christianity are in a situation and condition that is not empty. Before Christianity came there was a pre-Hindu "original" understanding. Then, came the Hindu religion that interacted with "authentic" understanding so that it gave birth to certain religus thoughts. Following Islam and Christianity, all of them interact and contribute to this religious thought. This existence is called spiritual culture ",

\footnotetext{
${ }^{1}$ E.G.Singgih, Berteologi Dalam Konteks (Yogyakarta: Kanisius, 2000). 83-84

${ }^{2}$ H. Berkhof dan I.H. Enklaar, Sejarah Gereja (Jakarta: BPK Gunung Mulia, 1967). 11

3 Josh McDowell dan Don Stewart, Handbook of Today's Religions (Nashville: Thomas Nelson Publisher, 1989).587
} 
because it is not part of religion even though it is spiritual, but it is part of culture. If culture with its spiritual-religious aspects is seen creatively, then it can be a means for Indonesian people to share their hearts with each the religion he encountered, then his content was not religious harmony but syncretism.

Only the second meaning above has a negative connotation. Actually if people talk about the dangers of syncretism today, then the meaning is as we see in this second meaning.

According to Indonesian Dictionary, Syncretism is a new understanding which is a combination of several different understandings to find harmony, balance and so on. ${ }^{4}$ According to Encyclopedia Syncretism is the process whereby two or more independent cultural systems, or elements thereof, conjoin to form a new and distinct system - is among the most important factors in the evolution of culture in general, but especially in the history of religion. ${ }^{5}$

To review in simple terms the two schools above, therefore, need to be defined what the Pentecostal-Charismatic actually is. A theologian named Menzies gives a presentation, Pentecost is:

Christians who believe that the Book of Acts provides a model for the church today and on this basis encourages every believer to experience baptism in the Spirit (Acts 2: 4), which is understood as giving power to preach the gospel, different from being born again, baptism The Spirit is marked by speaking in tongues, and affirming that "miracles and signs of wonder," include all gifts listed in 1 Corinthians 12: 8-10. Must characterize the church today. ${ }^{6}$

The term Pentecostal or Pentecostalism is often seen in the framework of denominative theology or ecclesiastical organizations. This is due to the various tendencies and excesses that were raised by the presence of split-oriented Pentecostal groups which at the same time represented the emergence of a new color of theology. ${ }^{7}$

Menzies also provides specific definitions of charismatics. According to him Charismatics are:

A Christian who believes that all the gifts listed in 1 Corinthians 12: 8-10, including the gift of prophecy, speaking in tongues, and the gift of healing, apply to

\footnotetext{
4 "Sinkretisme," n.d., https://kbbi.web.id.

5 "Syncretism," n.d., https://www.encyclopedia.com/philosophy-and-religion/bible/biblegeneral/syncretism.

${ }^{6}$ Robert P. Menzies, Pentecost: This Story Is Our Story. Teologi Pentakosta (Malang: Gandum Mas, 2015).14

7 Jan S. Aritonang, "Sejarah Pertumbuhan Gerakan Pentakostal Di Indonesia," Gema Teologika 1, no. 2 (2012), http://www.ukdw.ac.id/journal-theo/index.php/gema/article/view/132.
} 
the church today; but rejects the assertion that baptism in the Spirit (Acts 2: 4) is a power of attorney for evangelism different from the new birth. ${ }^{8}$

In etymology, Charismatics comes from the Greek word (Charism), which means grace. The gift of the Holy Spirit, more than what is needed for salvation. For the benefit of the church and the world, gifts are given to certain people or groups (1 Corinthians 12) and are always imbued with love (1 Corinthians 13: 1). In this context, the term "given knowledge" is often used. ${ }^{9}$ Charismatics revive the original spirit, which focuses on prophecy, speaking in tongues, healing sick people, and so on. Ecstasy and excitement are their characteristics. ${ }^{10}$

The charismatic movement is often also called charismatic renewal also known as the New Pentecost. Because of that, many times this movement is identified and mixed with the Pentecostal movement/church that emerged from the beginning. Certain spiritual experiences which are considered to be the main characteristics of spirit baptism and divine healing are also the main characteristics of the charismatic movement. Although in later developments this movement and pentecostal differences have little difference in appearance and manner of activity.

The charismatic movement is often also called charismatic renewal also known as the New Pentecost. Because of that, many times this gerkan is identified and mixed with the Pentecostal movement /church that emerged from the beginning. Certain spiritual experiences which are considered to be the main characteristics of spirit baptism and divine healing are also the main characteristics of the charismatic movement. Although in later developments this movement and pentecostal differences have little difference in appearance and manner of activity. ${ }^{11}$

\section{Methodology}

According to Stanley M Horton theology is built on five foundations namely: First, Canon Authority, second, Theological Authority, third ecclesiastical Authority, fourth Experience as authority, and fifth Common sense of mankind. According to Horton, exegesis and biblical theology are references in theology. ${ }^{12}$ The aspect of experience in developing systematic theology is something that the Pentecostal-Charismatic emphasizes greatly. In Pentecost-Charismatic experience is something that can be accounted for in biblical theology. This is often called

\footnotetext{
${ }^{8}$ Menzies, Pentecost: This Story Is Our Story. Teologi Pentakosta. 14

${ }^{9}$ Gerald O'Collins \& Edward G. Farrugia, Kamus Teologi (Yogyakarta: Kanisius, 1996).127

${ }^{10}$ Enklaar, Sejarah Gereja.331

11 166. Jan S. Aritonang, (Jakarta: BPK Gunung Mulia, 1995), Berbagai Aliran Di Dalam Dan Di Sekitar Gereja, Cet.Ke-2, n.d.196

12 Stanley M. Horton, Systematic Theology: A Pentecostal Perspective. Jilid 1 (Springfield, Missouri: Logion Press, 1994).42-45
} 
testimony. Testimony is a life experience that is part of God's plan, where believers experience relationships and help from God.

Grant Wacker explained the same thing in his book, which said that "Testimonies hold special importance in the Pentecostal movement. In the early days of Pentecostal movement, a testimony was treated as an import highlight in a service. $^{13 "}$

In accordance with the theological understanding of the PentecostalCharismatic movement that the baptism of the Holy Spirit is functioning as empowerment to be an effective witness. This is what drives PentecostalCharismatic people to prioritize testimony and give a place to become one of the important things in building theology.

\section{Characteristics of Pentecostal-Charismatic}

A movement that emphasizes the role of the gifts of the Holy Spirit. in summary, the pentecostal church has the following general characteristics: ${ }^{14}$

1. Strongly emphasizes the belief in the role of the Holy Spirit and the gifts of the Holy Spirit in the daily lives of its followers;

2. More modern spiritual songs;

3. Allow women to serve;

4. Relations between priests and congregations are more emphasized in family values.

\section{Impact of Analysis}

1. The emergence of the Charismatic movement is due to certain weaknesses in the church, such as the shallowness of religious life, the absence of fellowship and others, which are caused by inappropriate or inadequate service. In other words: the movement is a correction of certain deficiencies (mistakes) of the Church. The mistake is that the shortcomings are often exaggerated and consider themselves the only correct answer. In that way Charismatic not only does not help correct those shortcomings but makes it even worse

2. The aim and purpose of the Charismatic Movement is to provide members of the Church with a more intensive faith appreciation. It's good. But the appreciation of personal faith is so emphasized that individualism arises in the lives of its followers. The effort of this movement will be more beneficial if the appreciation of the individualist faith is replaced by the

${ }^{13}$ Grant Wacker, Heaven Below: Early Pentecostalism and American Culture (Cambridge: Harvard University Press, n.d.).3

14 "Gereja, Pentakosta," n.d., https://id.m.wikipedia.org/wiki/. 
appreciation of the shared faith and is directed towards the building of the life of fellowship in the church.

3. Most followers of the Charismatic movement have great missionary awareness. They constantly remind the Church of its work in the field of gospel message and evangelization. But because they emphasize spiritual efforts more, the issue of social politics hardly gets attention. The saddest is among those who contrast both the spiritual and the physical. This was also due to Pietism who continued to play an important role in the Charismatic Movement.

4. Followers of the Charismatic movement usually blame the Churches that the faith that is there is too much dogmatic and intellectual faith. That might be true. But in the Charismatic movement faith may be a reaction to the faith of members of the congregation often changing into emotional and uncritical faith. And such faith, consciously or unconsciously, can also create new dogmas or laws. For example, dogma requires that members of the church must follow a certain pattern of life. Or a new dogma that demands that all people must speak in tongues. Or dogma that says the gifts of the Spirit are true, without regard to other gifts such as teaching, serving, etc. These dogmas are actually incompatible in love by which new gifts get their true value (1 Cor. 13).

5. A new experience, which is not expected to immediately cause people to perceive it as true faith. It is clear that the Charismatic movement has a long experience of its followers in the past and with their past ecclesiastical experience, they have lived as something that is of little use. That attitude contains danger. For if past experience is not clarified, emotional experience will lead us to a dead end or an effort to continually gain new experiences.

6. One that is highlighted by Charismatic followers is the experience of the Spirit they obtain. It's a pity that they don't develop the teachings about the Spirit according to their experience.

7. The existence of the wrong attitude that is the attitude of contrasting the "new" and "the old" feeling with the mind, experience with thought, which is spiritual with the body, actual with historical, experience that is aware of the hidden work of the Spirit, the inner with the outward, piety with action and others.

\section{Theological Impact}

Personal experience is equalized into one truth as the Bible. The development of the pentecostal-charismatic movement also criticized many things 
in the church that were ritualistic and dogmatic. Therefore they replace those things with the freedom and dynamics of spirits that appear in spiritual phenomena. Enthusiasm, passionate enthusiasm and supernatural things are the colors of charismatic spirituality. Therefore, the personal experience of each person is given enormous space in their spiritual experience, while the theological reasoning of the charismatic movement is minimized.

Pentecostal-Charismatic revived practical and pious Christianity and reacted to the lukewarm atmosphere of the church, similar to the movement of Pietism that emerged in the early 17th century until it ended in the late 18th century. ${ }^{15}$ Biblical doctrines have been largely ruled out by the pentecostalcharismatic movement, while the personal experience of God has become more prominent.

\section{The Bible's view of syncretism}

In the Old and New Testament Scriptures we can see how the Bible always rejects syncretism in its true meaning. Therefore throughout the history of God's people in the Bible, it is full of struggles against syncretism. The Bible's rejection of syncretism is evident from the protests of God's prophets on the practice of worship to Baal, Babylonian rituals, Assyria and the attacks of New Testament writers on Hellenistic worship and Gnostic worship in Antioch, Ephesus, Corinth, Colossians, Rome.

The struggle against syncretism, First appeared in the meeting of the Israelites with people or nations in the land of Canaan who worshiped Baal, for example the Shechemites worshiped Baal Berit (Judges 8:33; 9:46), Moabites worshiping Baal Peor (Numbers 25: 3; Deuteronomy 4: 3; Hosea 9:10), the Philistines worshiped Baal Zebub (2 Kings 1: 2).

A higher and more complex wave of syncretism struck Israel about a century before exile, which took shape in the ways of worship, customs and culture of Babylon and Assyria. The syncretism was strongly opposed by the prophets, like the prophet Jeremiah (Jeremiah $2: 18 ; 2: 21 ; 2: 23 ; 2: 25-27$ ). As a result of Jeremiah's rebuke, King Josiah carried out a comprehensive reformation by focusing on worship in the Jerusalem Temple in 622 which was famous for the Deuteronomist reformation.

In the New Testament, when the Gospel came out of Israel, from the Jewish environment and began to reach Greece, the Hellenistic environment and the Gnostics there also met the gospel with the worship of foreign gods such as the

${ }^{15}$ Leonard Hale, Jujur Terhadap Pietisme (Jakarta: BPK Gunung Mulia, 1996).10-11 
worship of Isis and Sarapis from Egypt, Cybele and Attis from Syria, Mithra from Persia and philosophical schools such as Stoiki, Epicuri and Gnostics.

\section{Syncretism in the Age of Jesus}

Throughout the history of the church, since the beginning of the development of Christianity, syncretism between the Gospels preached by the church and other religions is indeed often the case. To see the relationship between the two, do you need to know first what the gospel is? In the Greek language "the Gospel" is called evangelion which means "good news" which is "the good news about Jesus Christ" which of course we learn from the Bible as God's Word. The Apostle Paul in his letter said that "... the gospel is the power of God that saves every believer ..." (Romans 1:16). Starting from the verse the notion of syncretism is the union and mixing of the path of salvation in Jesus Christ with the way of salvation preached by religions or other understandings.

In Jesus 'own ministry even though the Gospel can be heard directly from the mouth of Jesus, even in the time of Jesus' life, syncretism with hereditary traditions was inevitable. The Lord Jesus said: "This nation glorifies me with its lips, even though its heart is far from me. It is useless for them to worship me, while the teachings they teach are human commands. Your commandments are ignored to hold on to human customs." (Mark. 7: 6-8). Indeed syncretism with tradition is the most common even during Jesus' life, and consequently in addition to mixed teachings, it is often the case that traditional customs take precedence over the gospel of God.

\section{Syncretism in the Early Church}

After the New Testament, in the 11th century when the Gospel expanded and was accepted by nations including the Pax-Romanum (Great Roman), in addition to the temptation of syncretism with belief in Roman idols, a great temptation also occurred in the presence of eastern religious influences exotic and pantheistic (natural religion) originating from the colony east of the Mediterranean.

The Romans and Greeks who tended to be rational, especially in the first century to III, were challenged by mystical religious syncretism which taught the release that was pursued with an effort to fight (ascese). Eastern religion tends to practice "bertarak, restraint, turn off the lust of the flesh, and by taking parts in various ordinations and other secret ceremonies.

Reflecting through Acts can be seen as an example of syncretism in Philip's ministry in Samaria. Philip preached "the gospel of the kingdom of God and about the name of Jesus Christ" (Acts 8:12), but a sorcerer named Simon amazed many people (Acts 8:10) and even though he had confessed to believing 
and being baptized he was still syncretistic view where the concept of the gospel is still mixed with the concept of the Great Power. This means that it is not impossible for people to take advantage of the gospel and combine it with magic.

The principle of syncretism became a strong guess by several other church schools that developed in the Pentecostal-Charismatic movement. In this case Paul explicitly said. "Be careful that no one captures you with his empty and false philosophy according to hereditary teachings and the spirits of the world, but not according to Christ. For in him he abides physically all the fullness of Godhead" (Colossians 2: 8, 9).

\section{Syncretism in Pentecostal-Charismatic}

In the spiritual practice of some Pentecostal-Charismatic churches his teaching on the spirit often combines elements of superstition which do not conflict with the biblical understanding of spiritual reality. Teachings are often based on 'Scripture plus something'. That 'thing' can be experience, vision, dreams, prophecy, God's words directly, Rhema, etc. So that is inversely proportional to the slogan of the Reformation, namely Sola Scriptura (= only the Scriptures). Another understanding that can lead to syncretism is such an erroneous view of the Hermeneutic principle to the extreme that the Holy Spirit can teach them directly.

Practical syncretism can also be seen in the process of PentecostalCharismatic worship with regard to expression to God through excessive and uncontrolled sensory, emotional, and emotional experience. In a blurry and superficial introduction to the pattern of worship without the light of the word of God it is merely ritualism that is identical to the practice of mystisicm. While in the biblical concept this means, Jesus said "You worship what you don't know, we worship what we know ... (John 4:22). This means that the reality of the relationship with God is not built in a false way or experience but through a true and biblical introduction to God.

Although Pentecostal-Charismatic opponents of syncretism in their teaching, it is not impossible in practice that this can happen. Some of the teachings and practices of the Pentecostal-Charismatic school are often opposed by other Christian sects. As for some accusations to the Pentecostal-charismatic school regarding practical syncretism as follows:

1. Prosperity theology or prosperity the gospel, sometimes called successful theology, is Christian theology which teaches that prosperity and success (rich, successful, and perfectly healthy) are external signs from God to loved ones. ${ }^{16}$ Critics of prosperity theology claim that the doctrine is used

16 "Teologi Kemakmuran," 2019, https://id.wikipedia.org/wiki/Teologi_kemakmuran. 
by the news to benefit. They also say below that the focus of the doctrine on material wealth is wrong. They argue that material wealth can actually make believers fall into the love of money. ${ }^{17}$

2. Practical syncretism is also seen in the practice of anointing which is widely practiced by evangelists included in the Word of Faith Movement, as in the following expression: "Anointing is the revealed power and presence of God ... He believes that anointing can be transferred. careful to touch the person carelessly. 'It is not just a symbol - there is really an anointing transfer' ... If you raise your hand with the Spirit of God, and put it on someone's head, God's life in you will flow out of you into them. ${ }^{18}$ "

3. The Model of Worship in the Pentecostal-Charismatic movement provides a broad opportunity for actualization of identity for members of the congregation. This religious tendency will encourage others to experience peak experiences. In this case Pentecostal-Charismatic leads to the understanding of empiricism.

4. It cannot be denied that the Pentecostal-Charismatic church became so relevant and attracted the attention of many people. But on the other hand the lives of some popular preachers or pastors are so flamboyant and often seem pragmatic, materialist, hedonic.

From the facts above, it can be seen that syncretism practices emerged as a common phenomenon among Pentecostal-Charismatic schools. But keep in mind to look for these bright spots need to be examined theologically. Nicolas J Wolly Citing Kraemer's writing, the problem of syncretism according to Kraemer, is not just a matter of how a particular religion comes out further than just the translation and takeover of various ideas and practices from other religions around it (adaptation process). What is meant is that a religion goes further and further away from the real issue about the encounter between Christian faith and non-Christian religions. Adaptation of Kraemer's words, is not only avoided by Christians or the Christian community or the church but it is something that must happen and is imperative. $^{19}$

In the Scripture there are not many specific guidelines that Jesus has set out for people who are trying to connect with people who are committed to faith from other religious traditions. It seems that the clear guideline of the way Jesus relates to others is with love and mercy shown by accepting them for who they are. Hope S. Antone quoted Samson Prabhakar, a professor of Christian religious education from India as saying: "Why are we afraid of syncretism?" Tell me which

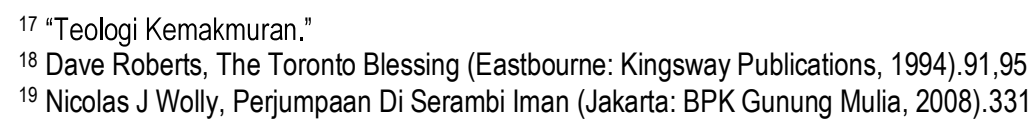


religion is not syncretistic. Is Judaism a pure religion? Is Christianity? ... I personally have no problem with syncretism as long as it strengthens and sustains life. Any syncretism that negates life should be avoided. ${ }^{20}$

Hope S Antone also quoted Devasahayam: "The political meaning of syncretism is nothing but playing the differences that cause disruption among various groups in society, and give greater attention to common enemies that threaten human life. In other words what is at risk is the safety of humanity itself. Joint witnessing becomes a joint exploration of the possibilities of human life. ${ }^{21}$

The author agrees with what was quoted by Hope S Antone, that Syncretism must be returned to its original meaning. Because remembering that the four meanings of syncretism above relate to political issues. This means "syncretism" is neutral. In accordance with what Jesus represented "I came, so that they might have life, and have it in all abundance (John 10:10).

\section{Pentecostal-Charismatic Contributions to Missiology}

Experience placement has played a role in Pentecost to present their message successfully, they have assumed that authentic spirituality has a dimension of experience and this has been championed in their evangelism and worship which are often dynamic and carefree. God believes that 'Experience, Enlightenment and Empowerment by the Holy Spirit, is the heart of Pentecostal missionology. Pentecost emphasized the freedom initiated by Roh which encouraged all participants to engage with God personally to be further enhanced to be the attraction of Pentecostal spirituality. The emphasis on experience also makes Pentecost the most interesting in a post-modern climate that also emphasizes the importance of individual choice and expression in experiencing one's spirituality. In this case Pentecost can offer something fundamentally related to spirituality in the form of ecstasy, a dimension that is dynamic in attending the Pentecostal service.

The next thing that became a contribution from the PentecostalCharismatic movement was development in mission and evangelism.

"Pentecostal and Charismatic believed that the spirit had been poured out on them to engage in the end-time harvest of souls that would accompany the preaching of" full gospel "throughout the world. ${ }^{22}$ "

Pentecostal-Charismatic has provided a new picture in terms of mission and evangelism that are different from "Missio Dei" from Catholics and Protestants in general. Anderson said "the heart of Pentecostal Mission is the experience of the

${ }^{20}$ Hope S. Antone, Pendidikan Kristiani Kontekstual (Jakarta: BPK Gunung Mulia, 2003).52

${ }^{21}$ Antone.

${ }^{22}$ Allan Anderson, An Introduction to Pentecostalism (USA: Cambridge University Press., 204AD).206 
power of the Spirit. ${ }^{23}$ So the mission for Pentecost is the experience of empowering the power of the Holy Spirit in evangelizing.

Pentecostal-Charismatics believe that the Holy Spirit still works until now giving power to believers to witness and give spiritual gifts to build the body of Christ, the church. Ishak Sugianto said: "With the descent of the Holy Spirit on Pentecost, Palestinian people 2,000 years ago saw a new lifestyle, namely a lifestyle full of the Holy Spirit." The Holy Spirit who fills the disciples gives them good power in what they say and what they do. This understanding of the Holy Spirit has also made a difference between Pentecostal-Charismatic and Evangelicals regarding the end of time.

\section{CONSLUSION}

Studies of religions view syncretism as a fusion phenomenon of various religious teachings and cults. Syncretism is considered a tendency that is not realized but is often confirmed by the interests of a broader interest. As long as humans are still there and the age continues to develop syncretism will certainly exist. Even though the tendency is often not realized, in practice it is often confirmed as a new teaching and culture. In this situation religious ideas are adjusted according to the religious principles of other religions. One of the syncretic choices is to take a clear line between culture and the gospel. But as a result there has been a development of multiple systems.

Syncretism is debated, especially in the Pentecostal-Charismatic school, must be responded with a cold head. Taking a wise attitude in understanding other religions needs to be taken early. Syncretism is arguably the joint decision-making process in overcoming various problems including those related to phenomena and theology.

In response to the phenomenological problem of Synchronism, the church must be wise. The more so if it is associated with methods and strategies and mission. The church should be open and not easy to be negative about all elements of change that are relevant and do not contain elements that are contradictory to the biblical foundation. But the church cannot accept each teaching as long as it is tested and analyzed carefully, but is more required to be sensitive, positive, selective and creative. Positive selectively and creatively the church can start, use and make use of what is there. And it negates the view that it harms or denies the Christian faith, especially those related to the gospel.

With the phrase Let you be rooted in Him and be built on Him, let you increase firmly in the faith that has been taught to you, and let your heart overflow

\footnotetext{
${ }^{23}$ Anderson.
} 
with gratitude (Colossians 2: 7). The Apostle Paul meant that: The Church of God is like a plant seed that is spread to grow and bear fruit in its own place where Christ is already there. Christianity must give independence in a responsible manner to the people in the new environment to understand, pervade, appreciate and express (express) their universal and transcendent faith in Christ according to their personality, culture and environment. This is legitimate and indeed has happened throughout the course of the history of Christianity.

\section{BIBLIOGRAPHY}

Anderson, Allan. An Introduction to Pentecostalism. USA: Cambridge University Press., 204AD.

Antone, Hope S. Pendidikan Kristiani Kontekstual. Jakarta: BPK Gunung Mulia, 2003.

Aritonang, Jan S. "Sejarah Pertumbuhan Gerakan Pentakostal Di Indonesia." Gema Teologika 1, no. 2 (2012). http://www.ukdw.ac.id/journaltheo/index.php/gema/article/view/132.

E.G.Singgih. Berteologi Dalam Konteks. Yogyakarta: Kanisius, 2000.

Enklaar, H. Berkhof dan I.H. Sejarah Gereja. Jakarta: BPK Gunung Mulia, 1967.

Farrugia, Gerald O'Collins \& Edward G. Kamus Teologi. Yogyakarta: Kanisius, 1996.

"Gereja, Pentakosta," n.d. https://id.m.wikipedia.org/wiki/.

Hale, Leonard. Jujur Terhadap Pietisme. Jakarta: BPK Gunung Mulia, 1996.

Horton, Stanley M. Systematic Theology: A Pentecostal Perspective. Jilid 1. Springfield, Missouri: Logion Press, 1994.

Jan S. Aritonang, (Jakarta: BPK Gunung Mulia, 1995), 166. Berbagai Aliran Di Dalam Dan Di Sekitar Gereja, Cet.Ke-2, n.d.

Menzies, Robert P. Pentecost: This Story Is Our Story. Teologi Pentakosta. Malang: Gandum Mas, 2015.

Roberts, Dave. The Toronto Blessing. Eastbourne: Kingsway Publications, 1994.

"Sinkretisme," n.d. https://kbbi.web.id.

Stewart, Josh McDowell dan Don. Handbook of Today's Religions. Nashville: Thomas Nelson Publisher, 1989.

"Syncretism," n.d. https://www.encyclopedia.com/philosophy-andreligion/bible/bible-general/syncretism.

"Teologi Kemakmuran," 2019. https://id.wikipedia.org/wiki/Teologi_kemakmuran.

Wacker, Grant. Heaven Below: Early Pentecostalism and American Culture. Cambridge: Harvard University Press, n.d.

Wolly, Nicolas J. Perjumpaan Di Serambi Iman. Jakarta: BPK Gunung Mulia, 2008. 